\title{
Apoptotic markers in semen of infertile men: Association with cigarette smoking
}

\author{
Nagla T. El-Melegy, Mohamed-Esam M. Ali
}

Medical Biochemistry (NTEM), Dermatology (MEMA) and Andrology (NTEM) Departments Faculty of Medicine, Assiut, Egypt

\begin{abstract}
Objectives: (i) To examine the role of apoptosis in the pathogenesis of DNA damage in semen from infertile men. (ii) To assess the effects of smoking on apoptotic markers and seminal parameters among infertile men. (iii) To assess the correlation of apoptosis with conventional semen parameters.

Materials and Methods: The study was carried out on 70 men with idiopathic infertility, divided into two groups: thirty infertile non smokers and forty infertile smokers. In addition to 60 fertile men (30 non smokers and 30 smokers) as control group. Each subject provided semen for analysis of parameters, determination of \% of DNA fragmentation, s-Fas, caspase- 3 activity levels and cotinine levels.

Results: The results revealed that infertile men, particularly smokers have significantly lower semen variables and significantly higher levels of apoptotic variables (\% of DNA fragmentation, s-Fas and caspase-3 activity) in addition to cotinine.

Conclusions: The present findings provide additional evidence supporting the importance of the evaluation of apoptotic markers to test male infertility particularly among smokers.
\end{abstract}

Key words: Apoptosis; smoking; DNA fragmentation; infertility; semen

Int Braz J Urol. 2011; 37: 495-506

\section{INTRODUCTION}

Despite worldwide anti-smoking campaigns, cigarette smoking is very common. A strong body of evidence has indicated the negative effect of cigarette smoking on male fertility (1).

Cotinine is widely applied as a marker of both tobacco use and exposure to environmental tobacco smoke because it has a longer half-life (average, 18 to 20 hours) than nicotine does (average, 2 to 3 hours) (2). The cotinine level was shown to be associated with modest reduction in semen quality, so smokers with marginal semen quality might be categorizes as infertile men. However, it is controversial whether nicotine or its metabolite cotinine are responsible for harmful effects on sperm kinetic parameters (3).

Many studies have associated cigarette smoking and male infertility; but the exact molecular mechanisms are not well understood (4).

Sperm DNA damage and sperm apoptosis have been considered as potentially useful indices of male fertility. Apoptosis is a mode of cellular death based on a genetic mechanism that induces a series of cellular, morphological and biochemical alterations, leading the cell death (5). In mammalian testes, clonal expansion is excessive and thus requiring a mechanism such as apoptosis to match the number of germ cells with the supportive capacity of Sertoli cells (6). Sperm DNA integrity is essential for the accurate transmission 
of genetic information. Any form of sperm chromatin abnormalities or DNA damage may result in male infertility $(7,8)$. Moreover, the study of Calogero et al., (9) showed that cigarettes smoke extract has a negative impact on sperm motility and DNA/chromatin integrity in a concentration- and time-dependent manner.

One factor implicated in sperm apoptosis is the cell surface protein, Fas. The interaction between Fas (CD95/Apo-1) a type I transmembrane glycoprotein receptor and cellular death inducing ligand a type II transmemberane glycoprotein (Fas L) plays an important role in triggering the apoptotic pathway. Both Fas and Fas L exist as membrane bound and soluble forms. It is suggested that sFas may be a marker of overall apoptosis triggering, at the same time regulating apoptosis by competing with the cell surface receptor. Previous reports have suggested that the Fasmediated system is implicated in the elimination of defective spermatozoa from the ejaculate and shows possible irregularities that could account for certain forms of male infertility (10-12).

The apoptotic cell death is a highly regulated process that in many cases requires activation of caspases, a superfamily of cysteine aspartyl-specific proteases. Caspase-3, an executioner caspase is thought to play a central role in apoptosis in a wide variety of cells. The presence of activated form of caspase-3 marks the point of no return within the complex apoptotic signaling cascade $(13,14)$. Interestingly, higher percentage of spermatozoa with activated caspases was found in infertile men confirming the existence of a caspase-dependant apoptotic pathway in ejaculated human sperm (15).

The objectives of the present study are: (i) To examine the role of apoptosis in the pathogenesis of DNA damage in semen from infertile men. (ii) To assess the effects of smoking on apoptotic markers and seminal parameters among infertile men. (iii) To assess the correlation of apoptosis with conventional semen parameters (sperm concentration, motility and morphology).

\section{MATERIALS AND METHODS}

The Ethics Committee of Faculty of Medicine, Assiut University approved the study. Informed consent was obtained from each par- ticipant before entering the study. The study was carried out on 70 men with idiopathic infertility who attended the Infertility Clinic of Andrology Department of Assiut University from May 2006 to June 2008. All of them had been married for $>$ 2 years and failed conception for $\geq 1$ year, with unprotected intercourse. They were diagnosed as idiopathic oligoasthenoteratozoospermia (iOAT). Female factors were excluded by a gynecologist as indicated by physical and laboratory examinations. A complete detailed infertility sheet was reviewed with each participant by a physician at the time of the physical examination. The sheet included information on occupation, smoking habits (e.g. number of cigarettes smoked per day, number of years of smoking, brand of cigarette, and whether or not others smoked in the house) and consumption of caffeine. Complete general and local genitalia examination were carried to exclude signs of hypogonadism. The genitalia were also, examined to exclude scrotal varicocele, cryptorchidism and congenital anomalies. Selected men had normal serum levels of growth hormone, FSH, LH, testosterone, estradiol, prolactin and thyroid hormones. The exclusion criteria included leucospermia, frank pyospermia, hemospermia or chronic urinary tract infection; history of intake of medications or tonics; azoospermia; and age above 45 years old, to avoid effects of aging on sperm variables. Also, any participants with history of injury to the testes, varicocele, hydrocele, undescended testis, history of chronic illness and long-term medication were excluded from the study. They were divided into two groups: thirty infertile nonsmokers with mean age $( \pm$ SD) $33.03 \pm 5.91$ years old and forty infertile smokers with mean age $( \pm$ SD) $31.60 \pm$ 5.10 years old. Smokers were categorized according to smoking status into mild $(\leq 10$ cigarettes per day), moderate ( $>10$ and $\leq 20$ cigarettes per day) and heavy smokers ( $>20$ cigarettes per day).

In addition, the study included 60 fertile men (controls): they were healthy subjects with normal semen parameters. The partners of fertile men had to be pregnant or to have delivered a child within the previous two years. They were divided into two groups (30 men each): Fertile 
Table 1 - Demographic variables and semen parameters in infertile men and fertile controls.

\begin{tabular}{|c|c|c|c|c|c|}
\hline \multicolumn{2}{|c|}{ Patients groups } & \multicolumn{2}{|c|}{ Fertile } & \multicolumn{2}{|c|}{ Infertile } \\
\hline & & $\begin{array}{c}\text { Group I } \\
\text { Non smokers } \\
(\mathrm{n}=30)\end{array}$ & $\begin{array}{c}\text { Group II } \\
\text { smokers }(n=30)\end{array}$ & $\begin{array}{c}\text { Group III } \\
\text { non smokers } \\
(\mathrm{n}=30)\end{array}$ & $\begin{array}{l}\text { Group IV } \\
\text { smokers } \\
(\mathrm{n}=40)\end{array}$ \\
\hline Age & Mean \pm SD & $31.83 \pm 4.33$ & $31.70 \pm 4.09$ & $33.03 \pm 5.91$ & $31.60 \pm 5.10$ \\
\hline \multirow[t]{2}{*}{ (years) } & Range & $25-40$ & $26-41$ & $24-45$ & $25-45$ \\
\hline & significance & & & $\dagger \mathrm{P} \mathrm{NS}$ & $\ddagger \mathrm{P} N \mathrm{NS}$ NS \\
\hline Number of & Mean \pm SD & - & $12.96 \pm 6.93$ & - & $14.60 \pm 7.12$ \\
\hline \multirow[t]{2}{*}{ cigarettes/day } & Range & - & $2-22$ & - & $2-25$ \\
\hline & & & & & $\ddagger \mathrm{P} \mathrm{NS}$ \\
\hline Duration of smoking & Mean \pm SD & - & $11.70 \pm 3.75$ & - & $12.02 \pm 5.23$ \\
\hline \multirow[t]{2}{*}{ (years) } & Range & - & $7-20$ & - & $5-27$ \\
\hline & & & & & $\ddagger$ PNS \\
\hline \multirow[t]{3}{*}{ Volume (mL) } & Mean \pm SD & $3.74 \pm 0.71$ & $3.31 \pm 0.89$ & $3.16 \pm 0.92$ & $3.07 \pm 0.88$ \\
\hline & Range & $2.5-5.5$ & $2-5$ & $1.5-5$ & $1.5-4.5$ \\
\hline & significance & & & $\dagger \mathrm{P}^{*}$ & $\ddagger \mathrm{P} N \mathrm{NS} \mathrm{PS}$ \\
\hline Sperm concentration & Mean $\pm \mathrm{SD}$ & $66.16 \pm 21.44$ & $61.66 \pm 19.84$ & $21.73 \pm 5.25$ & $18.85 \pm 4.27$ \\
\hline \multirow[t]{2}{*}{$\times 10^{6}$} & Range & $30-100$ & $30-100$ & $15-35$ & $10-27$ \\
\hline & significance & & & $\dagger \mathrm{P}^{* * *}$ & $\ddagger \mathrm{P}^{* * *} \S \mathrm{P} \mathrm{NS}$ \\
\hline \multirow[t]{3}{*}{ Motility \% (A+B) } & Mean \pm SD & $61.60 \pm 8.53$ & $58.60 \pm 5.35$ & $31.66 \pm 5.62$ & $29.90 \pm 4.72$ \\
\hline & Range & $50-80$ & $50-70$ & $25-40$ & $22-40$ \\
\hline & significance & & & $\dagger \mathrm{P}^{* * *}$ & $\ddagger \mathrm{P}^{* * *} \S \mathrm{P} \mathrm{NS}$ \\
\hline \multirow[t]{3}{*}{$\%$ of normal forms } & Mean $\pm \mathrm{SD}$ & $39.66 \pm 8.50$ & $35.00 \pm 5.08$ & $12.60 \pm 2.02$ & $10.05 \pm 1.43$ \\
\hline & Range & $30-60$ & $30-45$ & $10-17$ & $8-12$ \\
\hline & significance & & & $\dagger \mathrm{P}^{* * *}$ & $\$ \mathrm{P}^{* * *} \S \mathrm{P}^{*}$ \\
\hline
\end{tabular}

$\dagger P$ : group III versus I; $\not P$ : group IV versus II; $\S P$ : group IV versus III

***: $P<0.001 ; *: P<0.05$; NS: non significant

nonsmokers with mean age $( \pm \mathrm{SD}) 31.83 \pm 4.33$ years old and fertile smokers with mean age $( \pm$ SD) $31.70 \pm 4.09$ years old. Demographic variables and semen parameters in infertile men and fertile groups are presented in Table- 1 .
Semen samples: The samples were selfcollected into $50 \mathrm{~mL}$ sterile plastic screw-capped containers, after 3-5 days of sexual abstinence. They were allowed to liquefy for 30 minutes at room temperature $\left(22^{\circ} \mathrm{C}\right)$ and were then evaluated according to 
guidelines of World Health Organization criteria (16). The variables taken into consideration were: ejaculate volume $(\mathrm{mL})$, sperm concentration $\left(\mathrm{n} \times 10^{6} / \mathrm{mL}\right)$, forward motility (\%) (WHO A + B, where A and B indicate rapid and slow progressively motile spermatozoa, respectively) and morphology (\%normal forms). Morphological differentiation of sperms was carried out by light microscopy examination of the stained smears (by Spermac stain Kit, Catolog No FP09 SPS, supplied by Stain Enterprises Inc., RSA) (17).

Infertile patients with iOAT were selected with a sperm concentration of $<20$ million $/ \mathrm{mL}$, progressive motility (grade $\mathrm{A}+\mathrm{B}$ ) of $<50 \%$ with a decrease in rapid linear forward progression (grade A) of $<25 \%$ and $<30 \%$ of normal forms. Samples with a white blood cell count of $>1$ million $/ \mathrm{mL}$ or positive culture were excluded.

After the above analysis each sample was divided into two tubes, centrifuged at $1000 \mathrm{~g}$ for 10 min., followed by an additional centrifugation of the supernatant at $4000 \mathrm{~g}$ for $20 \mathrm{~min}$. The supernatant was collected and stored frozen at $-70^{\circ} \mathrm{C}$ to be used for assay of seminal Fas/Apo-1 and cotinine levels. The seminal pellet of one tube was reconstituted in warm trichloroacetic acid (TCA) $25 \%(1: 1, \mathrm{~V} / \mathrm{V})$ followed by centrifugation. Then the supernatant was collected and the pellet was reconstituted in $200 \mu \mathrm{L}$ hypotonic lysis buffer then each was stored frozen at $-70^{\circ} \mathrm{C}$ till time of assay of sperm DNA fragmentation. The seminal pellet of the second tube was reconstituted in 500 $\mu \mathrm{L}$ hypotonic lysis buffer then stored frozen at $-70^{\circ} \mathrm{C}$ till time of assay of the activity of caspase-3.

Sperm DNA fragmentation was determined by a colorimetric assay (18). Briefly, $200 \mu \mathrm{L}$ perchloric acid $(0.5 \mathrm{M})$ was added to the pellet (reconstituted in $200 \mu \mathrm{L}$ hypotonic lysis buffer) containing native DNA and to the supernatant containing fragmented DNA, followed by the addition of 2 volumes of a solution containing $0.088 \mathrm{M}$ diphenylamine, $98 \% \mathrm{~V} / \mathrm{V}$ glacial acetic acid, $1.5 \% \mathrm{~V} / \mathrm{V}$ sulfuric acid and $0.5 \%$ acetaldehyde solution. The samples were kept at $4{ }^{\circ} \mathrm{C}$ for 48 hours. The developed color was then spectrophotometrically measured at $575 \mathrm{~nm}$. The percentage of DNA fragmentation was expressed by the formula:

\section{Percent of DNA fragmentation $=\underline{\text { OD } 575 \text { supernatant } X 100}$} OD 575 supernatant + OD 575 pellet
Human Fas/Apo-1 levels were determined in seminal fluid by an ELISA technique using an immunoassay kit, (Cat. No. KHS 9502, supplied by Biosource International Inc. California, USA) (19). Seminal caspase-3 proteolytic activity was performed using the ApoTarget Caspase-3/CPP32 Colorimetric protease assay, Cat. No. KHZ0022 provided by Biosource International Inc. California, USA (20). The activity of caspase- 3 was calculated as a ratio of optical density of caspase- 3 to the protein concentration (mg) of each cell lysate. Protein concentration was determined by the method of Lowery et al. (21). Seminal plasma cotinine levels were determined by the chemical method described by Smith et al. (22).

\section{STATISTICAL ANALYSIS}

Data were analyzed using statistical program (SPSS Version 11). The results were presented as mean $\pm \mathrm{SD}$. Normally distributed data were analyzed using two tailed paired or unpaired student ttest while abnormally distributed data (skewed) were statistically analyzed using Mann-Whitney test. For multiple comparisons, one-way analysis of variance (ONE-WAY-ANOVA) test followed by Least Significant Difference (LSD) were used. Pearson correlation coefficient was used for correlations. A value of $p<$ 0.05 was considered to be significant.

\section{RESULTS}

The demographic variables and semen parameters in infertile men and fertile controls are presented in Table-1. Infertile men (non smokers and smokers) showed significant lower values of semen parameters in comparison to those of their corresponding controls. Infertile smokers showed significant lower \% of normal forms than that of non smokers $(p<0.05)$. Table- 2 demonstrates seminal plasma levels of \% of DNA fragmentation, s-Fas, caspase- 3 activity and cotinine in infertile men and fertile controls. Significant higher levels of semen $\%$ of DNA fragmentation, s-Fas caspase- 3 activity and cotinine were observed in infertile men particularly among smokers $(\mathrm{p}<0.001)$. Infertile men with heavy smoking status were significantly older in age, had a longer duration of smoking and had significant lower semen parameters than those of mild 
Table 2. Plasma levels of \% of DNA fragmentation, s-Fas, Caspase-3 activity and cotinine in infertile men and fertile controls.

\begin{tabular}{|c|c|c|c|c|c|}
\hline Parameters & & $\begin{array}{c}\text { \% of DNA } \\
\text { fragmentation }\end{array}$ & s-Fas $(n g / m L)$ & $\begin{array}{c}\text { Caspase-3 } \\
\text { (pmol/min/mg } \\
\text { protein) }\end{array}$ & $\begin{array}{l}\text { Cotinine } \\
(\mathrm{ng} / \mathrm{mL})\end{array}$ \\
\hline \multicolumn{6}{|l|}{ Group I } \\
\hline (Fertile non smokers) & Mean \pm SD & $8.206 \pm 2.974$ & $4.246 \pm 0.95$ & $22.333 \pm 4.68$ & $12.62 \pm 2.14$ \\
\hline$(\mathrm{n}=30)$ & Range & $3-13$ & $3-6.5$ & $15-30$ & $10-17$ \\
\hline Group II & & & $5.083 \pm 1.22$ & & $1068.3 \pm 173.9$ \\
\hline (Fertile smokers) & Mean $\pm \mathrm{SD}$ & $10.526 \pm 2.440$ & $3-7$ & $24.133 \pm 4.44$ & $800-1400$ \\
\hline$(\mathrm{n}=30)$ & Range & $6-15$ & & $17-32$ & \\
\hline \multicolumn{6}{|l|}{ Group III } \\
\hline (Infertile non smokers) & Mean \pm SD & $22.280 \pm 4.65$ & $8.756 \pm 0.87$ & $59.73 \pm 10.56$ & $13.35 \pm 2.75$ \\
\hline \multirow[t]{2}{*}{$(\mathrm{n}=30)$} & Range & $15-30$ & $7-10.5$ & $40-77$ & $9-19$ \\
\hline & & $\dagger \mathrm{P}^{* * *}$ & $\dagger \mathrm{P}^{* * *}$ & $\dagger \mathrm{P}^{* * *}$ & $\dagger \mathrm{P}: \mathrm{NS}$ \\
\hline \multicolumn{6}{|l|}{ Group IV } \\
\hline (Infertile smokers ) & Mean \pm SD & $30.550 \pm 6.26$ & $10.380 \pm 1.04$ & $67.75 \pm 9.16$ & $1355 \pm 259.1$ \\
\hline \multirow[t]{3}{*}{$(\mathrm{n}=40)$} & Range & $19-40$ & $8.5-12$ & $50-85$ & $1000-1800$ \\
\hline & & $\ddagger \mathrm{P}^{* * *}$ & $\sharp \mathrm{P}^{* * *}$ & $\sharp \mathrm{P}^{* * *}$ & $\ddagger \mathrm{P}^{* * *}$ \\
\hline & & $\S \mathrm{P} * * *$ & $\S \mathrm{P}^{* *}$ & $\S \mathrm{P} * * *$ & $\S \mathrm{P}^{* * *}$ \\
\hline
\end{tabular}

$\dagger P$ : group III versus I; $\ddagger$ P: group IV versus II; $\$ P$ : group IV versus III ***: $P<0.001 ; * *: P<0.01$; NS: non significant

and moderate smoking (Table-3). Also, significant higher levels of seminal \% of DNA fragmentation, sFas caspase- 3 activity and cotinine were observed in moderate and heavy smokers in comparison to those of mild smokers, with significant highest levels in heavy smokers $(\mathrm{p}<0.001)($ Table-4). Correlation coefficient (r) among various bioindices in infertile smokers is presented in Table-5. Significant positive correlations were observed between age, number of cigarettes/day, duration of smoking (years), $\%$ of DNA fragmenta- tion, s-Fas, caspase-3 activity and cotinine. Also, each of age, number of cigarettes/day, duration of smoking (years), \% of DNA fragmentation, s-Fas, caspase-3 activity and cotinine was significantly negatively correlated with each of semen parameters.

\section{DISCUSSION}

Many studies have examined the effects of cigarette smoking on male fertility and the results 
have suggested a substantial negative impact on sperm production, motility and morphology (23-26).

The present study revealed significant lower values of semen parameters (particularly in \% of normal forms) and significant higher $\%$ of DNA fragmentation and cotinine levels in semen of infertile smokers in comparison to those of the controls and infertile non smokers. These findings were very prominent among moderate and heavy smokers in comparison to those of mild smokers. Moreover, cotinine showed significant positive correlations with each of number of cigarettes smoked /day, duration of smoking and significant negative correlations with each of semen parameters.

Different studies have assessed the relationship between smoking and semen quality us-

Table 3. Demographic variables and semen parameters in infertile men according to smoking status.

\begin{tabular}{|c|c|c|c|c|}
\hline & & $\begin{array}{l}\text { Mild smokers } \\
\qquad(\mathrm{n}=10)\end{array}$ & $\begin{array}{l}\text { Moderate smokers } \\
\qquad(\mathrm{n}=19)\end{array}$ & $\begin{array}{c}\text { Heavy smokers } \\
(\mathrm{n}=11)\end{array}$ \\
\hline Age & Mean \pm SD & $26.50 \pm 1.26$ & $31.36 \pm 3.45$ & $36.63 \pm 4.98$ \\
\hline (years) & $\begin{array}{c}\text { Range } \\
\text { significance }\end{array}$ & $25-28$ & $\begin{array}{l}26-40 \\
\dagger \mathrm{P}^{* *}\end{array}$ & $\begin{array}{c}30-45 \\
\dagger \mathrm{P}^{* * *} \ddagger \mathrm{P} * * *\end{array}$ \\
\hline $\begin{array}{c}\text { Number of } \\
\text { cigarettes/day }\end{array}$ & $\begin{array}{c}\text { Mean } \pm \text { SD } \\
\text { Range } \\
\text { significance }\end{array}$ & $\begin{array}{c}5.0 \pm 2.44 \\
2-9\end{array}$ & $\begin{array}{c}14.84 \pm 3.43 \\
11-20 \\
\dagger \mathrm{P}^{* * *}\end{array}$ & $\begin{array}{c}22.90 \pm 1.70 \\
21-25 \\
\dagger \mathrm{P}^{* * *} \dagger \mathrm{P}^{* * *}\end{array}$ \\
\hline $\begin{array}{c}\text { Duration of } \\
\text { smoking (years) }\end{array}$ & $\begin{array}{l}\text { Mean } \pm \text { SD } \\
\text { Range }\end{array}$ & $\begin{array}{c}8.30 \pm 2.40 \\
5-11\end{array}$ & $\begin{array}{c}11.10 \pm 3.81 \\
5-20\end{array}$ & $\begin{array}{c}17.00 \pm 5.72 \\
10-27\end{array}$ \\
\hline & significance & & $\dagger \mathrm{PNS}$ & $\dagger \mathrm{P}^{* * *} \dagger \mathrm{P}^{* *}$ \\
\hline Volume (mL) & $\begin{array}{c}\text { Mean } \pm \text { SD } \\
\text { Range } \\
\text { significance }\end{array}$ & $\begin{array}{c}3.80 \pm 0.34 \\
3.5-5.5\end{array}$ & $\begin{array}{c}3.29 \pm 0.73 \\
2-4 \\
\dagger \mathrm{P}^{*}\end{array}$ & $\begin{array}{c}2.02 \pm 0.42 \\
1.5-2.5 \\
\dagger \mathrm{P}^{* * *} \ddagger \mathrm{P}^{* * * *}\end{array}$ \\
\hline $\begin{array}{c}\text { Sperm } \\
\text { concentration } \\
\times 10^{6} / \mathrm{mL}\end{array}$ & $\begin{array}{c}\text { Mean } \pm \text { SD } \\
\text { Range } \\
\text { significance }\end{array}$ & $\begin{array}{c}23.90 \pm 2.92 \\
18-27\end{array}$ & $\begin{array}{c}18.73 \pm 2.02 \\
15-22 \\
\dagger \mathrm{P}^{* * *}\end{array}$ & $\begin{array}{c}14.45 \pm 3.07 \\
10-19 \\
\dagger \mathrm{P}^{* * *} \doteqdot \mathrm{P}^{* * *}\end{array}$ \\
\hline Motility \% (A+B) & $\begin{array}{c}\text { Mean } \pm \text { SD } \\
\text { Range } \\
\text { significance }\end{array}$ & $\begin{array}{c}35.80 \pm 3.82 \\
31-40\end{array}$ & $\begin{array}{c}29.52 \pm 2.63 \\
25-35 \\
\dagger \mathrm{P}^{* * *}\end{array}$ & $\begin{array}{c}25.18 \pm 1.32 \\
22-27 \\
\dagger \mathrm{P}^{* * *} \ddagger \mathrm{P}^{* * *}\end{array}$ \\
\hline $\begin{array}{l}\% \text { of normal } \\
\text { forms }\end{array}$ & $\begin{array}{c}\text { Mean } \pm \text { SD } \\
\text { Range } \\
\text { significance }\end{array}$ & $\begin{array}{c}11.70 \pm 0.48 \\
11-12\end{array}$ & $\begin{array}{c}10.15 \pm 0.95 \\
8-12 \\
\dagger \mathrm{P}^{* * *}\end{array}$ & $\begin{array}{c}8.36 \pm 0.50 \\
8-9 \\
+\mathrm{P} * * * \pm \mathrm{P} * * *\end{array}$ \\
\hline
\end{tabular}

Mild smokers: ( $\leq 10$ cigarettes per day); Moderate smokers: ( $>10$ and $\leq 20$ cigarettes per day); Heavy smokers: (> 20 cigarettes per day). $\dagger P$ : versus mild smokers; $\Varangle P$ : versus moderate smokers; *: $P<0.05$; **: $P<0.01$; **: $P<0.001$; NS: non significant 
Table 4. Seminal plasma levels of \% of DNA fragmentation, s-Fas, Caspase-3 activity and cotinine in infertile men according to smoking status.

\begin{tabular}{|c|c|c|c|c|c|}
\hline Garameters & & $\begin{array}{c}\text { \% of DNA } \\
\text { fragmentation }\end{array}$ & s-Fas $(\mathrm{ng} / \mathrm{mL})$ & $\begin{array}{c}\text { Caspase-3 } \\
\text { (pmol/min/mg } \\
\text { protein) }\end{array}$ & Cotinine (ng/mL) \\
\hline Mild smokers & Mean \pm SD & $22.99 \pm 2.63$ & $9.09 \pm 0.40$ & $56.70 \pm 3.56$ & $1075 \pm 54.0$ \\
\hline$(\mathrm{n}=10)$ & Range & $19-27$ & $8.5-9.8$ & $50-62$ & $1000-1150$ \\
\hline Moderate smokers & Mean \pm SD & $30.45 \pm 4.10$ & $10.35 \pm 0.61$ & $67.89 \pm 6.08$ & $1313.1 \pm 158.8$ \\
\hline$(\mathrm{n}=19)$ & Range & $\begin{array}{l}22.5-38 \\
\dagger \mathrm{P} * * *\end{array}$ & $\begin{array}{l}9.2-12.0 \\
\dagger \mathrm{P}^{* * *}\end{array}$ & $\begin{array}{l}55-83 \\
\dagger \mathrm{P} * * *\end{array}$ & $\begin{array}{c}1100-1700 \\
\dagger \mathrm{P}^{* * *}\end{array}$ \\
\hline Heavy smokers & Mean \pm SD & $37.59 \pm 2.18$ & $11.60 \pm 0.31$ & $77.54 \pm 4.65$ & $1681.8 \pm 120.9$ \\
\hline$(\mathrm{n}=11)$ & Range & $\begin{array}{l}33.4-40 \\
\dagger \mathrm{P}^{* * *} \\
\ddagger \mathrm{P}^{* * *}\end{array}$ & $\begin{array}{l}11-12 \\
\dagger \mathrm{P} * * * \\
\$ \mathrm{P} * * *\end{array}$ & $\begin{array}{l}72-85 \\
\dagger \mathrm{P} * * * \\
\dagger \mathrm{P} * * *\end{array}$ & $\begin{array}{c}1450-1800 \\
\dagger \mathrm{P}: * * * \\
\ddagger \mathrm{P}^{* * *}\end{array}$ \\
\hline
\end{tabular}

Mild smokers: ( $\leq 10$ cigarettes per day).; Moderate smokers: (>10 and $\leq 20$ cigarettes per day); Heavy smokers: (>20 cigarettes per day). $\dagger P$ : versus mild smokers; $\sharp P$ : versus moderate smokers

***: $P<0.001$

NS: non significant

ing seminal cotinine as a measure of tobacco consumption. The present findings agree with those of previous studies $(1,3,25-28)$. On the contrary, some researches reported different results (29-32). They reported that smoking did not affect conventional semen variables. Moreover, Ozgur et al. (33) reported that heavy smokers have a higher percentage of rapidly progressive spermatozoa than light smokers. Hassa et al. (31) added that number of cigarettes/day did not correlate with any of sperm parameters. However, Collodel et al.,(26) reported that although the semen quality of males with idiopathic infertility seems to not be dramatically affected by cigarette consumption, heavy smokers show significantly lower sperm concentration. They attributed this discrepancy to the small size of sample group, or to the possibility that non-smoker patients may have been exposed to second hand smoke, which can cause immediate harm (23) and in particular, to prenatal exposure to tobacco smoke which has been demonstrated to have an adverse effect on semen quality (34).

The mechanism behind the harmful effect of smoking on semen quality is not fully understood. Disturbance of the hypothalamo-pituitary-gonadal system (35) or mild hypoxia caused by the disruption of the testicular microcirculation (36) are possible explanations, but a direct toxic effect of the many chemical components in cigarette smoking on the germinative epithelium is a more likely $(37,38)$. Oxidants in cigarette smoke are thought to damage sperm DNA, and smokers have more oxidative DNA damage in their sperm than do non-smokers (39). An adverse effect of reactive oxygen species (ROS) on sperm quality is a possibility that could justify the observed sperm damage, since elevated levels of ROS have been found in infertile smoking men $(28,40)$. Another causative factor would be the fact that seminal plasma in smokers contains lower levels of antioxidants than that of non smokers $(28,41)$. 
Table 5. Correlation coefficient (r) among various bioindices in infertile smokers.

\begin{tabular}{|c|c|c|c|c|c|c|c|}
\hline & Age & $\begin{array}{c}\text { Number of } \\
\text { cigarettes/day }\end{array}$ & $\begin{array}{c}\text { Duration of } \\
\text { smoking }\end{array}$ & $\begin{array}{c}\% \text { of } \\
\text { DNA } \\
\text { fragme } \\
\text { ntation }\end{array}$ & s-Fas & Caspase-3 & Cotinine \\
\hline $\begin{array}{l}\text { Number of } \\
\text { cigarettes/day }\end{array}$ & $0.790 * * *$ & & & & & & \\
\hline Duration of smoking & $0.897 * * *$ & $0.656^{* *}$ & & & & & \\
\hline$\%$ of DNA & $0.729 * *$ & $0.921 * * *$ & $0.643^{* *}$ & & & & \\
\hline fragmentation & & & & & & & \\
\hline s-Fas & $0.718 * *$ & $0.907 * * *$ & $0.617^{* *}$ & $0.908 * * *$ & & & \\
\hline Caspase-3 & $0.684^{* *}$ & $0.867 * * *$ & $0.575^{* *}$ & $0.919 * * *$ & $0.941 * * *$ & & \\
\hline Cotinine & $0.748 * * *$ & $0.913^{* * *}$ & $0.662^{* *}$ & $0.954 * * *$ & $0.888 * * *$ & $0.903 * * *$ & \\
\hline Volume & $-0.662 * *$ & $-0.786 * * *$ & $-0.673^{* *}$ & $-0.846^{* * *}$ & $-0.770 * *$ & $-0.788 * * *$ & $-0.893^{* * *}$ \\
\hline Sperm concentration & $-0.713 * *$ & $-0.858 * * *$ & $-0.581 * *$ & $-0.886^{* * *}$ & $-0.878^{* * *}$ & $-0.886^{* * *}$ & $-0.912 * * *$ \\
\hline Motility \% & $-0.688^{* *}$ & $-0.867 * * *$ & $-0.576^{* *}$ & $-0.884 * * *$ & $-0.886^{* * *}$ & $-0.879 * * *$ & $-0.861 * * *$ \\
\hline$\%$ of normal forms & $-0.751 * *$ & $-0.876^{* * *}$ & $-0.667^{* *}$ & $-0.878 * * *$ & $-0.869 * * *$ & $-0.863 * * *$ & $-0.913 * * *$ \\
\hline
\end{tabular}

Pearson's correlation was used.

**: $P<0.01$; ***: $P<0.001$

Sperm nuclear chromatin abnormalities/ DNA damage could occur at the time of or result from DNA packing at spermatogenesis (42). Alternatively, it could be the result of free-radical induced damage (43) or a consequence of apoptosis (44). The observed findings of the present study that infertile men with poor semen quality have increased DNA fragmentation agree with many other studies that established the fact that infertile men have higher DNA strand damage than fertile men (particularly in smokers) $(28,32,44-47)$. Moreover, $\%$ of DNA fragmentation was significantly negatively correlated with each of semen parameters. These findings are consistent with others $(5,45,46,48,49)$. However, they disagree with Sepaniak et al. (32); Saleh et al. (40). They concluded that sperm DNA damage analysis usually reveals hidden abnormalities in men with infertility that is classified as an idiopathic based on apparently normal semen parameters (40). Previous "in vivo" studies showed that benzo(a)pyrene, a carcinogenic polycyclic aromatic hydrocarbon resulting from cigarette combustion, is able to bind to DNA forming adducts. These adducts have been reported to be increased in spermatozoa of smoking men compared with non-smoking and show a direct correlation with plasma concentration of cotinine (50). However, Ex- 
posure of spermatozoa obtained from healthy men with normal sperm parameters to cigarette smoke extract (CSE) resulted in sperm apoptosis, suggested by the increased number of spermatozoa with phosphatidyl-serine (PS) externalization and with fragmented DNA (sign of late apoptosis) after both short- and long term incubation (9).

The regulation of apoptosis is based on the intracellular dominance of various proteins that induce or inhibit the apoptotic process (51). In the present study, seminal s-Fas levels were significantly higher in infertile men particularly among smokers with highest levels in heavy smokers. Also, significant negative correlations were observed between sFas and each of semen parameters. Similar findings were reported by previous studies. The Fas system is a widely recognized as a key physiological regulator of apoptosis of testicular germ cells (52). Sakkas et al. (11) reported that the number of spermatozoa expressing Fas is low in men with normal sperm parameters but higher in men with abnormal sperm parameters. They predicted that the Sertoli cells do not produce adequate levels of FasL and thus could not sufficiently trigger the Fas pathway in developing spermatogonia. Production of ejaculated spermatozoa that possess apoptotic markers, indicate that in some men with abnormal sperm parameters, an "abortive apoptosis" has taken place. They would therefore predict that the normal apoptotic mechanisms have, misfunctioned, been overridden, or not been completed due to the release of the "quasi-apoptotic" spermatozoa into the seminiferous tubule (53). However, the study of Pentikainen et al, (1999) (54) provided that the Fas system may, not be the only mechanism relied upon to mediate apoptosis in the testes as, interestingly, Fas- and FasL-deficient mice are fertile. Other systems may also play key roles in regulating apoptosis.

It is well known that one of the earliest and most consistent observed features of apoptosis is the activation of caspases. The present study showed significant higher levels of seminal caspase-3 activity in infertile men, particularly among smokers in comparison to those of the controls and infertile non smokers. Significant higher levels of seminal caspase- 3 activity were found in heavy smokers in comparison to those of mild and moderate smokers.
Also, significant negative correlations were observed between caspase- 3 and each of semen parameters. These findings agree with those of previous studies $(13,15,55,56)$.

Moreover, several lines of evidence associated low sperm motility and poor morphology with the presence of high caspase, regardless of the method for caspase determination $(14,56)$. Paasch et al. (15) reported that caspases are not completely removed during undisturbed spermatogenesis and may therefore be contributors of inhibition of normal sperm function. The present finding that seminal caspase-3 activity was significantly positively correlated with $\%$ of DNA fragmentation agree with those of previous reports $(13,14,56)$. Moreover, Weng et al. (13) found that $\%$ of DNA fragmentation appeared to be relatively higher than the percentage of sperm that had positive immunostaining for active caspase-3. They attributed this to a temporal dissociation between caspase activation and the expression of cellular changes suggestive of apoptosis. Alternatively, triggering of PS externalization and DNA fragmentation could be due to activation of other caspases or cellular pathways. Understanding of these mechanisms may provide the means to manipulate apoptosis for therapy.

The present study, also, revealed significant negative correlation between age and each of semen parameters. These findings are consistent with those of others (57-60). Levitas et al. (59) added that the most significant reduction in sperm parameters occurred after the age of 55 years old. However it disagrees with those of Chen et al. (61); Winkle et al. (62). However, in an earlier study they found inverse associations between age and sperm concentration, motility and morphology. They attributed those findings to an older population of males compared to their earlier study (63). Also, age was significantly positively correlated with the studied apoptotic markers. These findings disagree with those of Gandini et al. (64) as they did not find any correlation in studied groups. They added that this is not an absolute finding and relates only to the patients in their study.

\section{Study limitations}

The present study has the following limitations: small number of the studied subjects. Another limitation is that the information on current smoking 
was, as all other variables, collected through self-completed questionnaires, which may have introduced a risk of misclassification of the exposure variable and lack of accurate smoking dose information. Nevertheless, underreporting of current smoking would have caused the underestimation of the true association.

\section{CONCLUSIONS}

The present findings support the importance of apoptotic markers evaluation to workup male infertility, particularly among smokers. Moreover, cigarette smoking may have negative impact on sperm quality and DNA integrity. Therefore, it would be advisable for men to abstain from smoking to avoid decreased fertility.

\section{CONFLICT OF INTEREST}

None declared.

\section{REFERENCES}

1. Soares SR, Melo MA: Cigarette smoking and reproductive function. Curr Opin Obstet Gynecol. 2008; 20: 281-91.

2. Caraballo RS, Giovino GA, Pechacek TF, Mowery PD, Richter PA, Strauss WJ, et al.: Racial and ethnic differences in serum cotinine levels of cigarette smokers: Third National Health and Nutrition Examination Survey, 1988-1991. JAMA. 1998; 280: 135-9.

3. Hassan A, Abo-Azma SM, Fayed SM, Mostafa T: Seminal plasma cotinine and insulin-like growth factor-I in idiopathic oligoasthenoteratozoospermic smokers. BJU Int. 2009; 103: 108-11.

4. Arabi M, Moshtaghi H: Influence of cigarette smoking on spermatozoa via seminal plasma. Andrologia. 2005; 37: 119-24.

5. Chen Z, Hauser R, Trbovich AM, Shifren JL, Dorer DJ, Godfrey-Bailey L, et al.: The relationship between human semen characteristics and sperm apoptosis: a pilot study. J Androl. 2006; 27: 112-20.

6. Sinha Hikim AP, Swerdloff RS: Hormonal and genetic control of germ cell apoptosis in the testis. Rev Reprod. 1999; 4: 38-47.
7. Agarwal A, Said TM: Role of sperm chromatin abnormalities and DNA damage in male infertility. Hum Reprod Update. 2003; 9: 331-45.

8. Barroso G, Morshedi M, Oehninger S: Analysis of DNA fragmentation, plasma membrane translocation of phosphatidylserine and oxidative stress in human spermatozoa. Hum Reprod. 2000; 15: 1338-44.

9. Calogero A, Polosa R, Perdichizzi A, Guarino F, La Vignera S, Scarfia A, et al: Cigarette smoke extract immobilizes human spermatozoa and induces sperm apoptosis. Reprod Biomed Online. 2009; 19: 56471.

10. Lee J, Richburg JH, Younkin SC, Boekelheide K: The Fas system is a key regulator of germ cell apoptosis in the testis. Endocrinology. 1997; 138: 2081-8.

11. Sakkas D, Mariethoz E, St John JC: Abnormal sperm parameters in humans are indicative of an abortive apoptotic mechanism linked to the Fas-mediated pathway. Exp Cell Res. 1999; 251: 350-5.

12. Zedan H, El-Mekhlafi AW, El-Noweihi AM, Abd ElAzim NE, Mostafa T: Soluble Fas and gonadal hormones in infertile men with varicocele. Fertil Steril. 2009; 91: 420-4.

13. Weng SL, Taylor SL, Morshedi M, Schuffner A, Duran EH, Beebe S, et al.: Caspase activity and apoptotic markers in ejaculated human sperm. Mol Hum Reprod. 2002; 8: 984-91.

14. Lozano GM, Bejarano I, Espino J, González D, Ortiz A, García JF, et al.: Relationship between caspase activity and apoptotic markers in human sperm in response to hydrogen peroxide and progesterone. J Reprod Dev. 2009; 55: 615-21.

15. Paasch U, Grunewald S, Fitzl G, Glander HJ: Deterioration of plasma membrane is associated with activated caspases in human spermatozoa. J Androl. 2003; 24: 246-52.

16. World Health Organization. World Health Organization Laboratory Manual for Examination of Human Semen. Cambridge: Cambridge University Press. 1999.

17. Menkveld R, Stander FS, Kotze TJ, Kruger TF, van Zyl JA: The evaluation of morphological characteristics of human spermatozoa according to stricter criteria. Hum Reprod. 1990; 5: 586-92.

18. Perandones CE, Illera VA, Peckham D, Stunz LL, Ashman RF: Regulation of apoptosis in vitro in mature murine spleen T cells. J Immunol. 1993; 151: 3521-9.

19. Cifone MG, De Maria R, Roncaioli P, Rippo MR, Azuma M, Lanier LL, et al.: Apoptotic signaling through CD95 (Fas/Apo-1) activates an acidic sphingomyelinase. J Exp Med. 1994; 180: 1547-52. 
20. Talanian RV, Quinlan C, Trautz S, Hackett MC, Mankovich JA, Banach D, et al.: Substrate specificities of caspase family proteases. J Biol Chem. 1997; 272: 9677-82.

21. Lowery $\mathrm{OH}$, Rosenbrough NJ, Farr AL, Randall RI: rotein measurement with Folin phenol reagent. J Biol Chem. 1951; 193: 265-8.

22. Smith RF, Mather HM, Ellard GA: Assessment of simple colorimetric procedures to determine smoking status of diabetic subjects. Clin Chem. 1998; 44: 275-80.

23. Dorfman SF: Tobacco and fertility: our responsibilities. Fertil Steril. 2008; 89: 502-4.

24. Künzle R, Mueller MD, Hänggi W, Birkhäuser $M H$, Drescher H, Bersinger NA: Semen quality of male smokers and nonsmokers in infertile couples. Fertil Steril. 2003; 79: 287-91.

25. Ramlau-Hansen $\mathrm{CH}$, Thulstrup AM, Aggerholm AS, Jensen MS, Toft G, Bonde JP: Is smoking a risk factor for decreased semen quality? A cross-sectional analysis. Hum Reprod. 2007; 22: 188-96.

26. Collodel G, Capitani S, Pammolli A, Giannerini V, Geminiani M, Moretti E: Semen quality of male idiopathic infertile smokers and nonsmokers: an ultrastructural study. J Androl. 2010; 31: 108-13.

27. Zavos PM, Correa JR, Antypas S, Zarmakoupis-Zavos $\mathrm{PN}$, Zarmakoupis CN: Effects of seminal plasma from cigarette smokers on sperm viability and longevity. Fertil Steril. 1998; 69: 425-9.

28. Elshal MF, El-Sayed IH, Elsaied MA, El-Masry SA, Kumosani TA: Sperm head defects and disturbances in spermatozoal chromatin and DNA integrities in idiopathic infertile subjects: association with cigarette smoking. Clin Biochem. 2009; 42: 589-94.

29. Sergerie M, Ouhilal S, Bissonnette F, Brodeur J, Bleau G: Lack of association between smoking and DNA fragmentation in the spermatozoa of normal men. Hum Reprod. 2000; 15: 1314-21.

30. Trummer H, Habermann H, Haas J, Pummer K: The impact of cigarette smoking on human semen parameters and hormones. Hum Reprod. 2002; 17: 1554-9.

31. Hassa H, Yildirim A, Can C, Turgut M, Tanir HM, Senses T, et al.: Effect of smoking on semen parameters of men attending an infertility clinic. Clin Exp Obstet Gynecol. 2006; 33: 19-22.

32. Sepaniak S, Forges T, Gerard H, Foliguet B, Bene MC, Monnier-Barbarino P: The influence of cigarette smoking on human sperm quality and DNA fragmentation. Toxicology. 2006; 223: 54-60.

33. Ozgur K, Isikoglu M, Seleker M, Donmez L: Semen quality of smoking and non-smoking men in infertile couples in a Turkish population. Arch Gynecol Obstet.
2005; 271: 109-12.

34. Ramlau-Hansen CH, Thulstrup AM, Storgaard L, Toft $\mathrm{G}$, Olsen J, Bonde JP: Is prenatal exposure to tobacco smoking a cause of poor semen quality? A follow-up study. Am J Epidemiol. 2007; 165: 1372-9.

35. Vermeulen A: Environment, human reproduction, menopause, and andropause. Environ Health Perspect. 1993; 101(Suppl 2): 91-100.

36. Collin O, Kilter S, Bergh A: Tobacco smoke disrupts testicular microcirculation in the rat. Int J Androl. 1995; 18: 141-5. Erratum in: Int J Androl. 1995; 18: 230.

37. Zenzes MT: Smoking and reproduction: gene damage to human gametes and embryos. Hum Reprod Update. 2000; 6: 122-31.

38. Kumosani TA, Elshal MF, Al-Jonaid AA, Abduljabar HS: The influence of smoking on semen quality, seminal microelements and Ca2+-ATPase activity among infertile and fertile men. Clin Biochem. 2008; 41: 1199-203.

39. Horak S, Polanska J, Widlak P: Bulky DNA adducts in human sperm: relationship with fertility, semen quality, smoking, and environmental factors. Mutat Res. 2003; 537: 53-65.

40. Saleh RA, Agarwal A, Nelson DR, Nada EA, El-Tonsy $\mathrm{MH}$, Alvarez JG, et al.: Increased sperm nuclear DNA damage in normozoospermic infertile men: a prospective study. Fertil Steril. 2002; 78: 313-8.

41. Pasqualotto FF, Umezu FM, Salvador M, Borges E Jr, Sobreiro BP, Pasqualotto EB: Effect of cigarette smoking on antioxidant levels and presence of leukocytospermia in infertile men: a prospective study. Fertil Steril. 2008; 90: 278-83.

42. Sailer BL, Jost LK, Evenson DP: Mammalian sperm DNA susceptibility to in situ denaturation associated with the presence of DNA strand breaks as measured by the terminal deoxynucleotidyl transferase assay. J Androl. 1995; 16: 80-7.

43. Aitken RJ, Gordon E, Harkiss D, Twigg JP, Milne P, Jennings $Z$, et al.: Relative impact of oxidative stress on the functional competence and genomic integrity of human spermatozoa. Biol Reprod. 1998; 59: 1037-46.

44. Evenson DP, Wixon R: Clinical aspects of sperm DNA fragmentation detection and male infertility. Theriogenology. 2006; 65: 979-91.

45. Sun JG, Jurisicova A, Casper RF: Detection of deoxyribonucleic acid fragmentation in human sperm: correlation with fertilization in vitro. Biol Reprod. 1997; 56: 602-7.

46. Irvine DS, Twigg JP, Gordon EL, Fulton N, Milne PA, Aitken RJ: DNA integrity in human spermatozoa: relationships with semen quality. J Androl. 2000; 21: 33-44. 
47. Mahfouz RZ, Sharma RK, Said TM, Erenpreiss J, Agarwal A: Association of sperm apoptosis and DNA ploidy with sperm chromatin quality in human spermatozoa. Fertil Steril. 2009; 91: 1110-8.

48. Chan PJ, Corselli JU, Patton WC, Jacobson JD, Chan SR, King A: A simple comet assay for archived sperm correlates DNA fragmentation to reduced hyperactivation and penetration of zona-free hamster oocytes. Fertil Steril. 2001; 75: 186-92.

49. Saleh RA, Agarwal A, Nada EA, El-Tonsy MH, Sharma RK, Meyer A,vet al.: Negative effects of increased sperm DNA damage in relation to seminal oxidative stress in men with idiopathic and male factor infertility. Fertil Steril. 2003; 79(Suppl 3): 1597-605.

50. Zenzes MT, Bielecki R, Reed TE: Detection of benzo(a)pyrene diol epoxide-DNA adducts in sperm of men exposed to cigarette smoke. Fertil Steril. 1999; 72: 330-5.

51. Cayli S, Sakkas D, Vigue L, Demir R, Huszar G: Cellular maturity and apoptosis in human sperm: creatine kinase, caspase-3 and Bcl-XL levels in mature and diminished maturity sperm. Mol Hum Reprod. 2004; 10: 365-72.

52. Fujisawa M, Ishikawa T: Soluble forms of Fas and Fas ligand concentrations in the seminal plasma of infertile men with varicocele. J Urol. 2003; 170: 2363-5.

53. Sakkas D, Moffatt O, Manicardi GC, Mariethoz E, Tarozzi N, Bizzaro D: Nature of DNA damage in ejaculated human spermatozoa and the possible involvement of apoptosis. Biol Reprod. 2002; 66: 1061-7.

54. Pentikäinen V, Erkkilä K, Dunkel L: Fas regulates germ cell apoptosis in the human testis in vitro. Am J Physiol. 1999; 276: E310-6.

55. Marchetti C, Gallego MA, Defossez A, Formstecher P, Marchetti P: Staining of human sperm with fluorochrome-labeled inhibitor of caspases to detect activated caspases: correlation with apoptosis and sperm parameters. Hum Reprod. 2004; 19: 1127-34.

56. Almeida C, Cardoso MF, Sousa M, Viana P, Gonçalves A, Silva J, et al.: Quantitative study of caspase-3 activity in semen and after swim-up preparation in relation to sperm quality. Hum Reprod. 2005; 20: 1307-13.

57. Centola GM, Eberly S: Seasonal variations and agerelated changes in human sperm count, motility, motion parameters, morphology, and white blood cell concentration. Fertil Steril. 1999; 72: 803-8.

58. Kidd SA, Eskenazi B, Wyrobek AJ: Effects of male age on semen quality and fertility: a review of the literature. Fertil Steril. 2001; 75: 237-48.

59. Levitas E, Lunenfeld E, Weisz N, Friger M, Potashnik G: Relationship between age and semen parameters in men with normal sperm concentration: analysis of 6022 semen samples. Andrologia. 2007; 39: 45-50.

60. Mukhopadhyay D, Varghese AC, Pal M, Banerjee SK, Bhattacharyya AK, Sharma RK, et al.: Semen quality and age-specific changes: a study between two decades on 3,729 male partners of couples with normal sperm count and attending an andrology laboratory for infertility-related problems in an Indian city. Fertil Steril. 2010; 93: 2247-54.

61. Chen Z, Godfrey-Bailey L, Schiff I, Hauser R: Impact of seasonal variation, age and smoking status on human semen parameters: The Massachusetts General Hospital experience. J Exp Clin Assist Reprod. 2004; 1: 2.

62. Winkle T, Rosenbusch B, Gagsteiger F, Paiss T, Zoller $\mathrm{N}$ : The correlation between male age, sperm quality and sperm DNA fragmentation in 320 men attending a fertility center. J Assist Reprod Genet. 2009; 26: 41-6.

63. Chen Z, Toth T, Godfrey-Bailey L, Mercedat N, Schiff I, Hauser R: Seasonal variation and age-related changes in human semen parameters. J Androl. 2003; 24: 226-31.

64. Gandini L, Lombardo F, Paoli D, Caponecchia L, Familiari G, Verlengia C, et al.: Study of apoptotic DNA fragmentation in human spermatozoa. Hum Reprod. 2000; 15: 830-9.

Submitted for publication:

December 08, 2010

Accepted after revision:

Abril, 15, 2011

Correspondence address:

Dr. Nagla T. El Melegy

Medical Biochemistry Department,

Faculty of Medicine, Assiut University, Assiut,

Egypt

Postal code of Assiut University: 71515

Fax: +002 0882333327

E-mail: elmelegynagla@yahoo.com 